\title{
The Time Duration of the Effects of Total Extraction Mining Methods on Surface Movement
}

\author{
André Vervoort \\ Department of Civil Engineering, KU Leuven, 3001 Leuven, Belgium; andre.vervoort@kuleuven.be; \\ Tel.: +32-16-321171
}

Received: 16 July 2020; Accepted: 6 August 2020; Published: 8 August 2020

\begin{abstract}
Since the 1990s, remote sensing data have been available to monitor the surface movement for long periods of time. The analysis of satellite data shows that there is still residual subsidence (i.e., with average rates of about $-10 \mathrm{~mm} /$ year) several decades after mining longwall panels in an area. Several years after the underground infrastructure was sealed, the surface started to move upwards. In the past, it often was claimed that movement of the surface was limited in time, i.e., a few years after mining a longwall panel. This is not the case for the conditions of the Campine coal basin, Belgium. This knowledge is important when one wants to design new operations in deep coal seams, but also when planning to stop the underground mining and to seal the access to the mine.
\end{abstract}

Keywords: longwall coal mining; ground control; subsidence; uplift; surface movement; radar-interferometry; long-term behavior; sustainable mining; Belgium

\section{Introduction}

There is general agreement that the total extraction mining method, such as longwall mining with the associated goaf, has an impact on the environment, e.g., the subsidence of the surface [1-5]. It also is obvious that this impact is permanent, but that issue is not the focus of this paper. The problem being addressed herein is whether the surface movement will be an ongoing phenomenon long after all mining activities have stopped or whether the movement will reach a state of complete, stabilized equilibrium after a certain period. Generally, the people in the industry, as well as researchers, have the opinion that the surface movement is limited in time. Often, it is claimed that subsidence only occurs over a period of a few months to a few years and that, subsequently, the ground is stable. Some researchers divide the process of subsidence into various phases [6-9]. They identify the first phase as initial subsidence and the second phase that is referred to as either principal, accelerated, or steady-state subsidence. The third phase is referred to as residual, differed, or delayed subsidence, and it is assumed to be limited in time. After the third phase, it is assumed that the subsidence has stopped and that the ground is stable [7]. Some examples of time periods for the residual phase from various places in the world are given by Al Heib et al. [7], and their conclusion is as follows: "The duration of the residual subsidence phase is about 12 to 18 months, but this duration is often less long, i.e., about 3 to 4 months when the exploitation is carried out in an already disturbed zone (several seams, goaf, ... ). There are some isolated cases resulting from geological contexts and/or particular exploitation, for these cases, the duration of residual subsidence can appreciably be raised and spread out over one period of 4 to 6 years." The end of the residual subsidence phase is defined as either (1) when an amount of additional subsidence corresponding to a certain percentage of the subsidence during the two previous phases has been reached, (2) when the increments between successive measurements have become negligible, or (3) when a predefined fixed time period has been reached.

The basis for conducting the research presented in this paper was not a specific interest in long-term subsidence; rather, it was the occurrence of partly unexpected and new behavior of the 
surface movement several years after the closure of the last coal mines in northeastern Belgium around $1990[10,11]$. A few years after the closure of the underground infrastructure and the dismantling of the underground pumping stations, the surface started to move upward. This phenomenon first was observed in the Netherlands, where the coal mines were closed in the 1970's [12]. Efforts to understand and explain this uplift phenomenon led to the study of the residual subsidence prior to the start of uplift, and hence, to the study of the long-term impact of deep coal mining.

The Campine basin belongs to the Upper Carboniferous strata (Westphalian stage). It is part of the South Permian basin of northwestern Europe [10]. Mainly coking or metallurgical coal was mined, with an average calorific value of $35 \mathrm{MJ} / \mathrm{kg}$. The overburden contains sand, clay and chalk; i.e., all weak geological material. The total thickness of the overburden varies between 400 and $600 \mathrm{~m}$. It contains several aquifers and aquitards [13]. The waste rock between the mined coal seams is composed mainly of shale, siltstone, sandstone, and thin (unmined) coal layers. Overall, the successive layers of waste rock are relatively thin (on the order of decimeter to meter in scale).

\section{Global View of Surface Movement after the Closure of Mines}

This paper presents data for the western part of the Belgian Campine basin in northeastern Belgium. Three coal mines were active in that part of the basin, i.e., from west to east, the Beringen, Zolder, and Houthalen mines [10]. The depths of the mining in the western part of the Belgian Campine basin varied from $-485 \mathrm{~m}$ to $-967 \mathrm{~m}$. The mining height for a single longwall varied from $0.5 \mathrm{~m}$ to $3.3 \mathrm{~m}$, with an average of $1.5 \mathrm{~m}$. In most areas, 5 to 10 coal seams were mined above each other. Coal production started for the three mines between 1922 and 1939, and all of the production was terminated between 1990 and 1992. The underground pumping stations were dismantled, and the shafts were closed in the years after the production was terminated. This western part of the Campine basin was characterized by a period of additional residual subsidence that was followed by uplift. An earlier study showed that a residual downward movement occurred for the Houthalen coal mine until the end of 1999, which was followed by limited surface movement from 2000 through 2004, and a clear uplift since 2005 [13]. However, spatial variations were observed.

Taking the timing of closure and the subsequent periods of residual subsidence and uplift into account, the images of the European C-band ERS1/2 and ENVISAT-ASAR satellites were the most suitable. These data were acquired for research through a European Space Agency (ESA) research proposal [14]. The periods that were recorded for the two sets were from August 1992 through December 2000 ( 87 cycles of 35 days) and from December 2003 through October 2010 (72 cycles of 35 days), respectively. Radar interferometry or Interferometry with Synthetic Aperture Radar (InSAR) is very suitable for studying large time series over large surface areas. The movements of reflective surfaces (i.e., the so-called "permanent scatterers" or "reflectors") were followed during all successive cycles of the satellite. This allowed the acquisition of significant spatial coverage of the areas that were studied, at least if the areas were part of a built environment.

Figure 1 presents a global view of the surface movement in the period of mainly residual subsidence (Figure 1a), and in the period of mainly uplift (Figure 1b), for the entire surface area above and around the three coal mines. For comparison purposes, the surface movement was extrapolated to a total time period of 10 years for each Figure. Hence, Figure 1a covers the period from August 1992 through August 2002, and Figure $1 \mathrm{~b}$ covers the period from March 2003 through March 2013. As the variation as a function of time is not always linear (see further), the increase of surface subsidence over the last 20 months in the first period was added to the value recorded for December 2000, while for the second period the increase in uplift during the first nine months and the last 29 months were added. Since $1 \mathrm{~mm} /$ year generally is accepted as a possible error on the trend of surface movement recorded by these satellites $[15,16]$, only reflectors with a minimum additional movement of $10 \mathrm{~mm}$ over 10 years are presented. The outside borders of the zone of the longwall panels that were mined are presented by straight blue lines. The data clearly show that the reflectors with a significantly larger movement occurred mainly within these borders or in the immediate vicinity. 


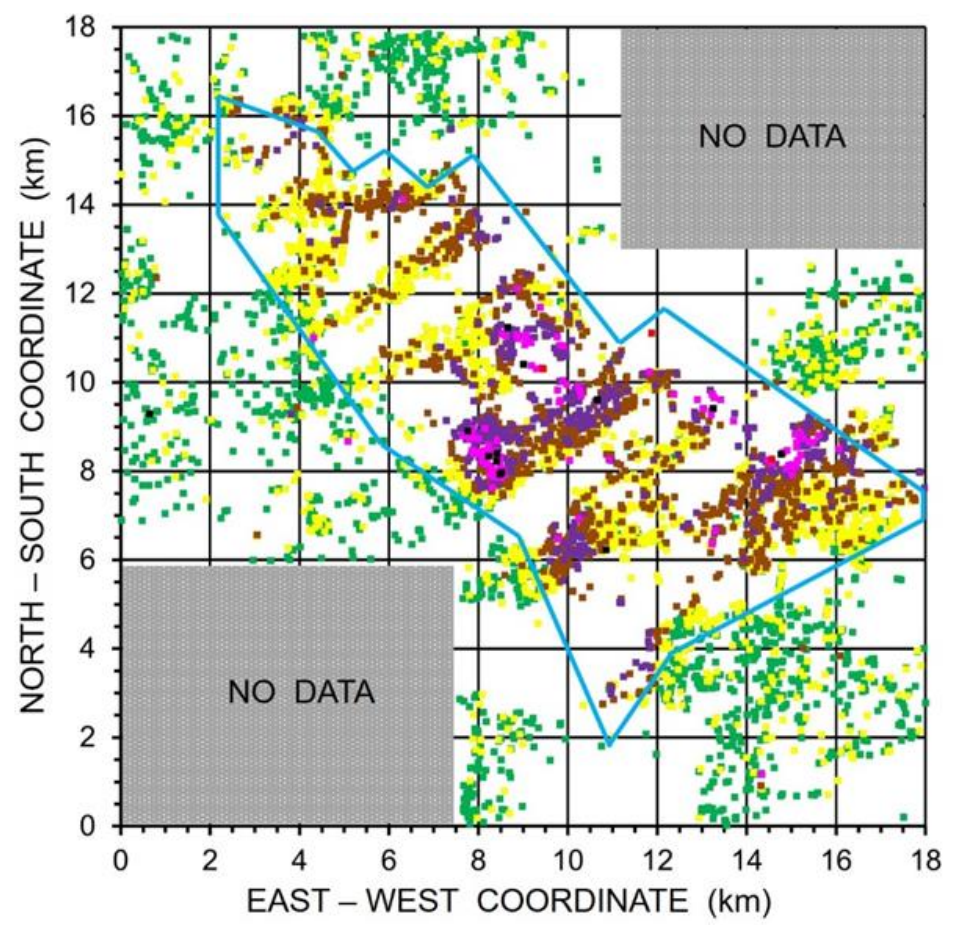

(a)

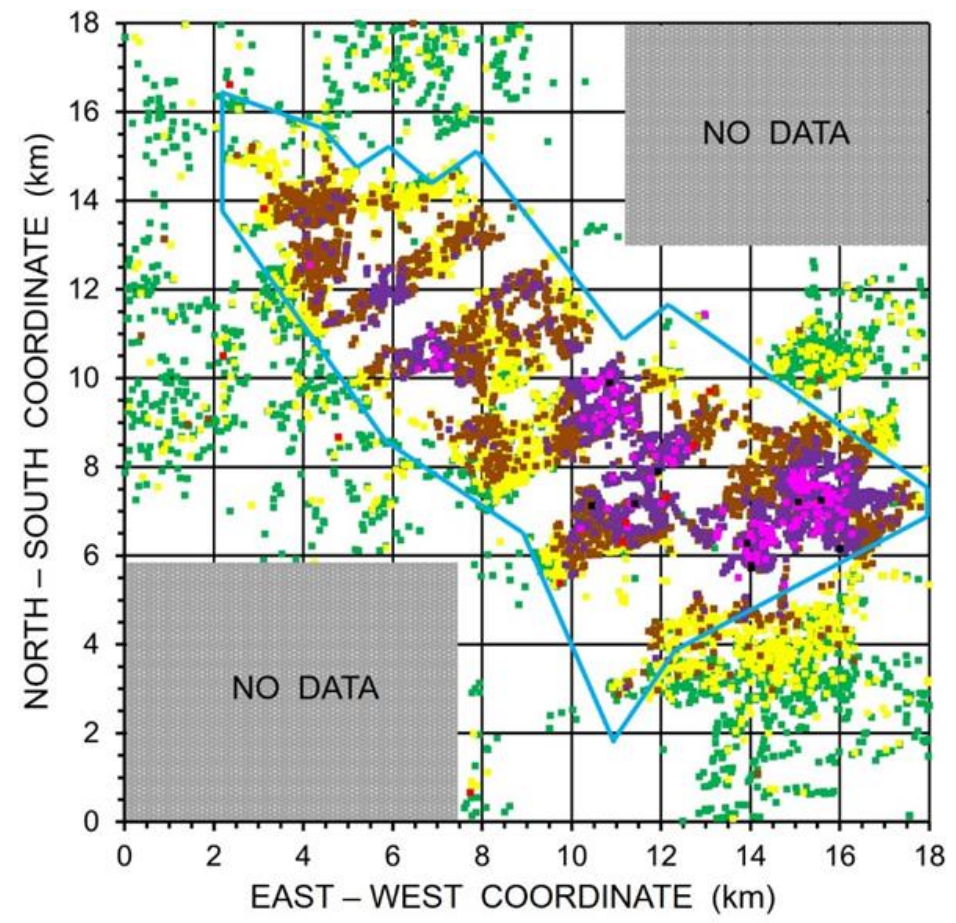

-10 to $-25 \mathrm{~mm}$

-25 to $-50 \mathrm{~mm}$

घ-50 to $-75 \mathrm{~mm}$

- -75 to $-100 \mathrm{~mm}$

= -100 to $-125 \mathrm{~mm}$

- -125 to $-150 \mathrm{~mm}$

a-150 or more mm
च 10 to $25 \mathrm{~mm}$

25 to $50 \mathrm{~mm}$

- 50 to $75 \mathrm{~mm}$

- 75 to $100 \mathrm{~mm}$

100 to $125 \mathrm{~mm}$

- 125 to $150 \mathrm{~mm}$

- 150 or more $\mathrm{mm}$

(b)

Figure 1. Spatial distribution of additional surface movement over a period of 10 years: (a) Period from August 1992 through August 2002, residual subsidence larger than -10 mm; (b) period from March 2003 through March 2013, uplift larger than $10 \mathrm{~mm}$. The outside borders of the zone of the mined longwall panels are shown with the blue color. 
However, some (smaller) movements are also recorded outside these borders. For a single panel, the angle of draw in the Campine basin is often assumed to be $45^{\circ}$ [5]. In other words, the size of the zone of influence is approximately the depth of mining. Recent research has shown that this is an underestimation when looking at the entire coal basin. In Reference [5], this is illustrated by some examples: At about $3 \mathrm{~km}$ further than the boundary a systematic surface movement was recorded over a period of 20 years, while at a distance of $7 \mathrm{~km}$ no movement at all was recorded. As discussed later, by analyzing long-term frequent data series over large areas, new insights occur. With conventional levelling campaigns, one has the tendency to limit the area of monitoring and to stop monitoring once the difference in surface movement between successive levelling campaigns becomes equal to the accuracy of the levelling method.

Figure 2 presents the reflectors with an additional surface movement within $\pm 10 \mathrm{~mm}$ over 10 years, as well as the reflectors with the opposite movement from the global trend (i.e., already uplift in the first period and still residual subsidence in the second period). In comparison to Figure 1, these two groups of reflectors now are situated mainly outside the mined area. In other words, one can conclude definitively that both types of movements (downward and upward) are linked to mining. The other conclusion is that two decades after the closure of the mine, there is still movement of the surface, and one cannot assume that the strata are stabilized.

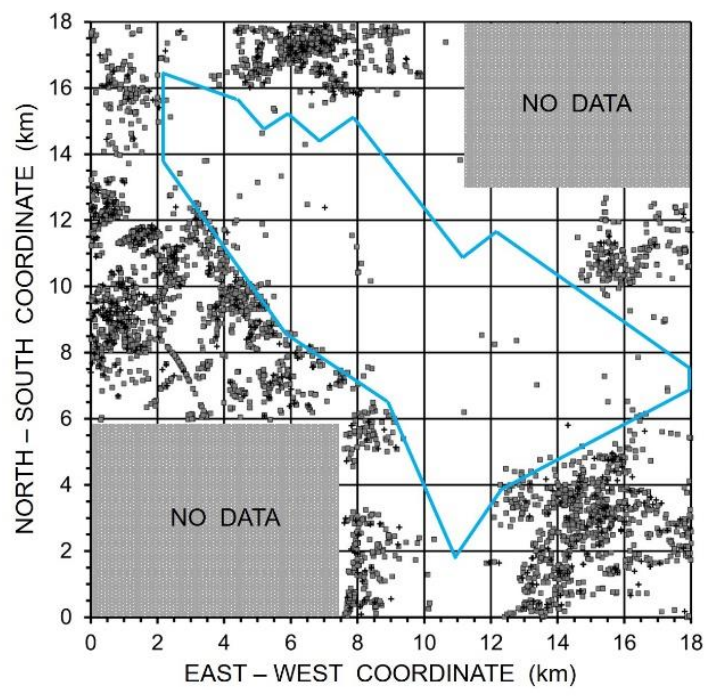

(a)

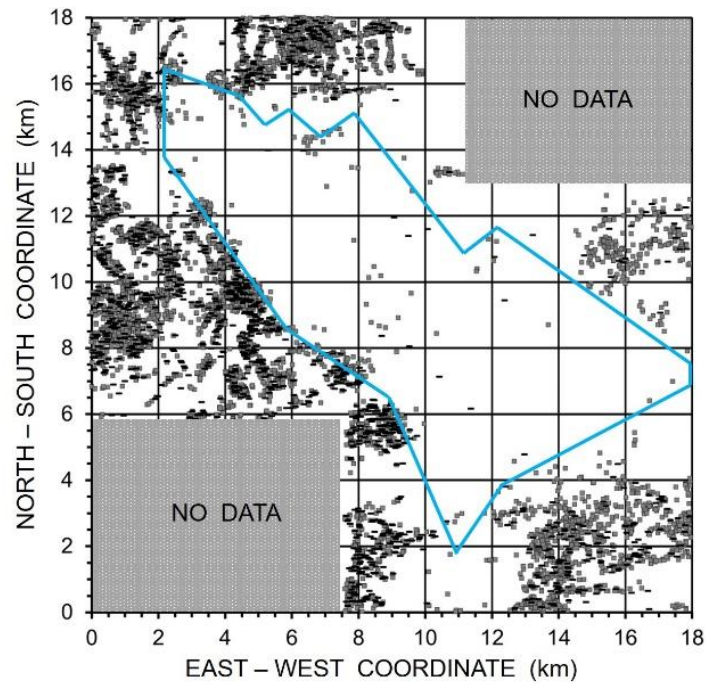

(b)

Figure 2. Spatial distribution of the reflectors with an additional surface movement of $\pm 10 \mathrm{~mm}$ over 10 years (grey squares), as well as the reflectors with the movement that is opposite of the global trend (plus and minus signs, respectively): (a) Period from August 1992 through August 2002; (b) period from March 2003 through March 2013.

Globally, about one and a half to two times more reflectors were detected with the more modern second satellite (ENVISAT-ASAR) than with the first (European C-band ERS1/2). Some sub-areas within the mined area do not have any reflectors, e.g., the band between the east-west, north-south coordinates $(4.5 \mathrm{~km}, 10.5 \mathrm{~km})$ and $(9.0 \mathrm{~km}, 13.0 \mathrm{~km})$. These gaps where there are no reflectors in Figure 1 correspond to zones composed of natural land, forest, lakes, and agricultural land. Also, the area to the northeast of the mined area is such land.

When comparing in detail the spatial distribution of the surface movements between Figure 1a,b, one cannot conclude that the sub-areas with large residual subsidence correspond with sub-areas of large uplift. For example, in the northwest, the large uplift values for coordinates $(6,12)$ in Figure $1 \mathrm{~b}$ (uplift values of mainly 75 to $100 \mathrm{~mm}$ over 10 years) correspond mainly to residual subsidence values of -25 to $-75 \mathrm{~mm}$ in Figure 1a. Something similar can be observed for the entire western part in the 
northwest sub-area, i.e., within the east-west distance of 3 to $5 \mathrm{~km}$ and north-south between 11 and $14.5 \mathrm{~km}$. Another example is the entire zone between east-west 11 and $17 \mathrm{~km}$ and north-south between 6 and $7 \mathrm{~km}$. This zone is characterized by large uplift values and relatively low residual subsidence values. However, the zone around coordinates $(8,8)$ is characterized by high residual subsidence values (mainly -100 to $-150 \mathrm{~mm}$ ) and low uplift values $(25$ to $75 \mathrm{~mm}$ ). All of these observations are in agreement with earlier research results $[11,17]$ that showed that the spatial distributions of the residual subsidence values and the uplift values were different, and no correlation was observed between these two parameters. This information is useful in trying to understand the mechanisms that cause an uplift in comparison to the mechanisms that cause subsidence, as will be discussed later.

\section{Surface Movement as A Function of Time Since Mining the Last Longwall Panel}

\subsection{Residual Subsidence}

Since the overall research is focused on the new phenomenon, i.e., the occurrence of uplift several years after the closure of the underground infrastructure, four locations were selected that had relatively high uplift values.

Table 1 gives the coordinates of these four locations, which are referred to as the black, blue, green, and red locations. A sub-area was defined around each location in which 10 reflectors were present in the first observation period, i.e., the period with residual subsidence. The number of 10 reflectors was considered a good compromise between being able to calculate a meaningful average and not having a too large effect of the spatial variation.

Table 1. Information on the five sub-areas selected for detailed analyses (Figures 3-5): Coordinates of the central point in sub-area; depth interval and mining period of all longwall panels within extended sub-area; number of reflectors and minimum, average, and maximum additional surface movement (average rate between brackets) for both observation periods.

\begin{tabular}{|c|c|c|c|c|c|c|c|c|}
\hline \multirow{5}{*}{ Sub-Area } & \multirow{5}{*}{$\begin{array}{c}\text { East-West } \\
(\mathbf{k m})\end{array}$} & \multirow{5}{*}{$\begin{array}{l}\text { North-South } \\
(\mathbf{k m})\end{array}$} & \multirow{5}{*}{$\begin{array}{l}\text { Depth } \\
\text { Interval } \\
\text { (m) }\end{array}$} & \multirow{5}{*}{$\begin{array}{l}\text { Mining } \\
\text { Period }\end{array}$} & \multicolumn{2}{|c|}{$\begin{array}{l}\text { First Period } \\
\text { (8.37 year) }\end{array}$} & \multicolumn{2}{|c|}{$\begin{array}{l}\text { Second Period } \\
\text { (6.92 year) }\end{array}$} \\
\hline & & & & & $\mathbf{N}^{\circ}$ & Min & $\mathbf{N}^{\circ}$ & Min \\
\hline & & & & & & Av & & Av \\
\hline & & & & & & Max & & Max \\
\hline & & & & & \multicolumn{2}{|c|}{ (mm (mm/year)) } & \multicolumn{2}{|c|}{$\begin{array}{c}(\mathrm{mm} \\
(\mathrm{mm} / \text { year }))\end{array}$} \\
\hline Black & 15.1 & 7.1 & $-560 \ldots-966$ & $1939 \ldots 1973$ & 10 & $\begin{array}{l}-25.8(-3.1) \\
-39.1(-4.7) \\
-48.5(-5.8)\end{array}$ & 20 & $\begin{array}{c}35.3(5.1) \\
62.8(9.1) \\
80.6(11.7)\end{array}$ \\
\hline Blue & 10.8 & 9.1 & $-607 \ldots-820$ & $1932 \ldots 1989$ & 10 & $\begin{array}{l}-31.9(-3.8) \\
-54.0(-6.5) \\
-65.2(-7.8)\end{array}$ & 20 & $\begin{array}{c}53.5(7.7) \\
68.2(9.9) \\
83.3(12.0)\end{array}$ \\
\hline Green & 5.8 & 11.9 & $-637 \ldots-804$ & $1933 \ldots 1962$ & 10 & $\begin{array}{l}-27.7(-3.3) \\
-36.7(-4.4) \\
-51.7(-6.2)\end{array}$ & 18 & $\begin{array}{l}40.7(5.9) \\
55.2(8.0) \\
64.5(9.3)\end{array}$ \\
\hline Red & 8.8 & 12.1 & $-632 \ldots-800$ & $1968 \ldots 1974$ & 10 & $\begin{array}{l}-53.8(-6.4) \\
-60.6(-7.2) \\
-76.2(-9.1)\end{array}$ & 20 & $\begin{array}{l}26.0(3.8) \\
42.6(6.2) \\
57.5(8.3)\end{array}$ \\
\hline Brown & 15.3 & 8.6 & $-609 \ldots-967$ & $1940 \ldots 1992$ & 10 & $\begin{array}{c}-66.8(-8.0) \\
-80.4(-9.6) \\
-103.7(-12.4)\end{array}$ & 20 & $\begin{array}{l}25.4(3.7) \\
37.1(5.4) \\
45.2(6.5)\end{array}$ \\
\hline
\end{tabular}




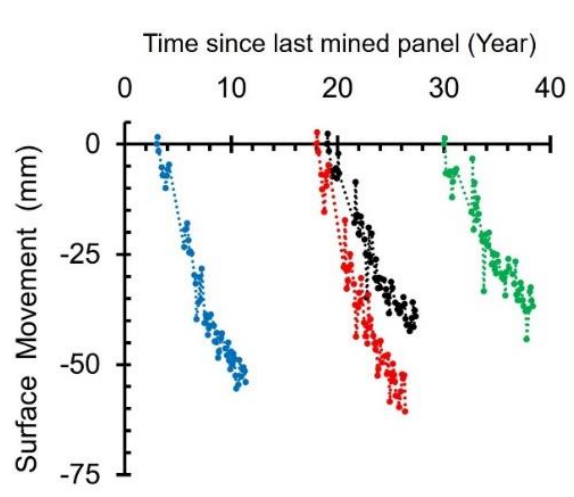

(a)

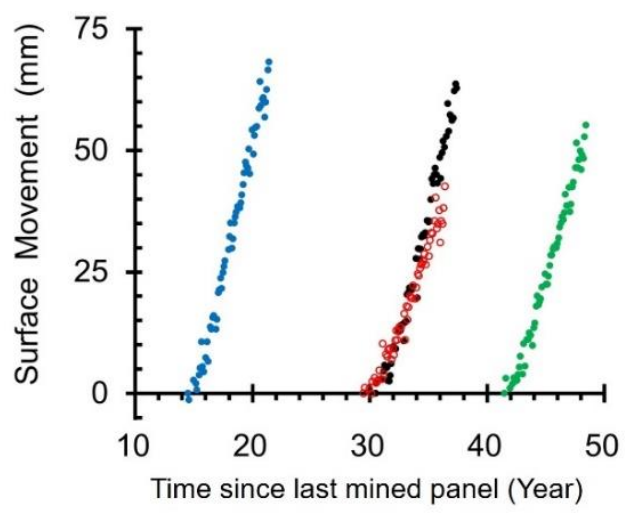

(b)

Figure 3. Variation of the average additional surface movement as a function of time since the last mined longwall panel for four sub-areas in the vicinity: (a) Period from August 1992 through December 2000; (b) period from December 2003 through October 2010.

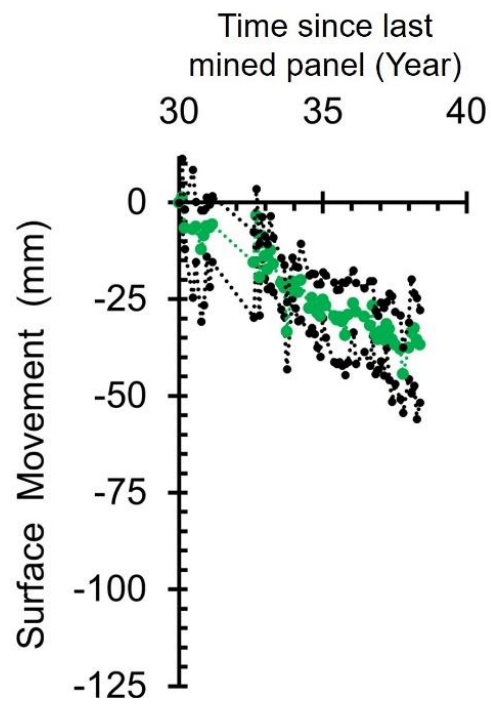

(a)

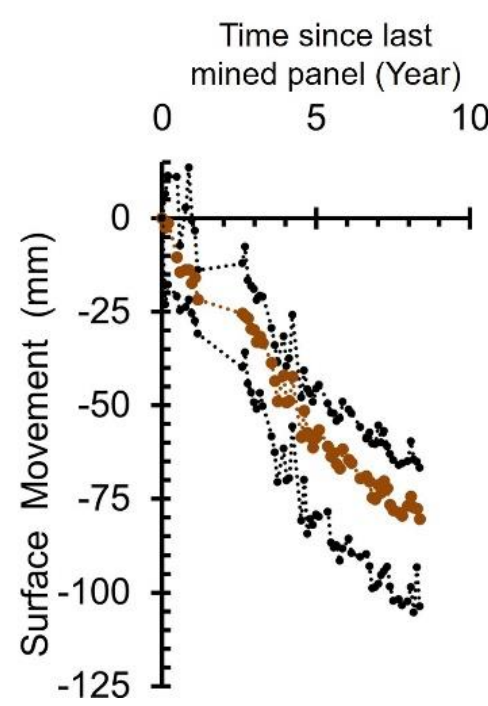

(b)

Figure 4. Variation of the minimum, average, and maximum residual subsidence as a function of time since the last mined longwall panel in the vicinity for two sub-areas over the period from August 1992 through December 2000: (a) Sub-area green; (b) sub-area brown.

This sub-area was extended further, reaching $1 \mathrm{~km}$ to the north, south, east, and west. All of the longwall panels that intersected this extended sub-area were considered, and the year of the most recent panel was taken as the origin of the time scale (Figure 3). An extension of $1 \mathrm{~km}$ was considered an acceptable distance for the zone of influence because it is larger than the maximum depth of mining. Figure 3 a shows the variations of the average residual subsidence for the four sub-areas from August 1992 through December 2000. In comparison to the two previous Figures, the data of the satellite images are not extrapolated in Figure 3.

For all four sub-areas, residual subsidence is still occurring. For the green sub-area, this movement is occurring even though it has been 40 years since mining was done in the vicinity. Figure 4a shows the variation of the minimum, average, and maximum residual subsidence for this green sub-area. Note that the curve of the maximum values does not necessarily correspond to a single reflector. The same is true for the minimum values. The differences between the extreme values are relatively low, i.e., the values vary from -27.7 to $-51.7 \mathrm{~mm}$ over the period of 8.37 years with an average additional subsidence of $-36.7 \mathrm{~mm}$. The latter corresponds to an average annual rate of $-4.4 \mathrm{~mm} /$ year. 
The differences between the minimum and maximum annual rates over the entire period with the average are 1.1 and $1.8 \mathrm{~mm} /$ year, respectively.

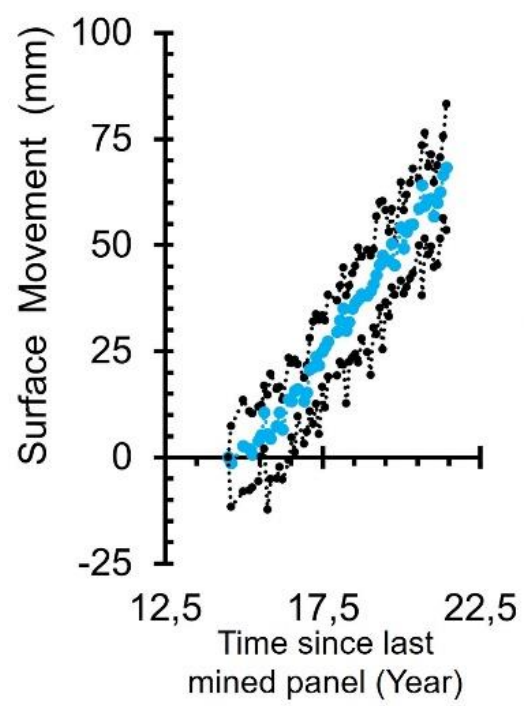

(a)

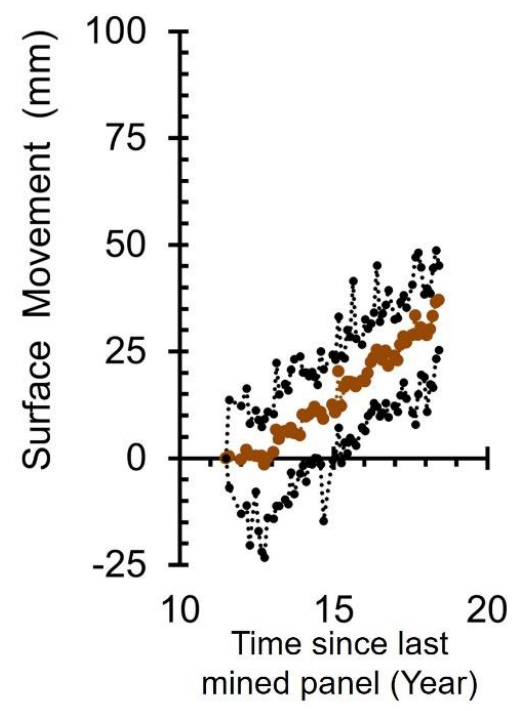

(b)

Figure 5. Variation of the minimum, average, and maximum uplift as a function of time since the last mined longwall panel in the vicinity for two sub-areas over the period from December 2003 through October 2010: (a) Sub-area blue; (b) sub-area brown.

Similar conclusions can be reached for the other sub-areas. (See Table 1 for the details.) The spread between the minimum and the maximum rates is a combination of both the inaccuracy of the measurement method and the impact of the spatial variation. Earlier research showed that the larger the study area is, the more variation there is. However, it was observed that by considering shorter time intervals, the larger the variation in the annual rates is. For an area with 117 reflectors, Vervoort and Declercq [13] estimated that the average rate over the first observation period (8.37 years) varied from -2.8 to $-8.7 \mathrm{~mm} /$ year for these reflectors (so, per reflector, the average was calculated over the entire time period). However, the largest annual increase that was observed was $-30 \mathrm{~mm} / \mathrm{year}$.

Figure $4 \mathrm{~b}$ shows an example of the residual subsidence of a sub-area (brown) in which a longwall panel was mined just before the mine was closed. It also is a sub-area with relatively high residual subsidence values and lower uplift values. The central coordinates of this sub-area are $(15.3,8.6)$. The additional residual subsidence varies between -66.8 and $-103.7 \mathrm{~mm}$. The average annual rate over the entire time period is $-9.6 \mathrm{~mm} /$ year. (The extremes are -8.0 and $-12.4 \mathrm{~mm} /$ year, respectively.) So, the average annual rate is more than twice the rate of the green sub-area, which was the smallest of the four sub-areas of Figure $3 a$.

For the entire area presented in Figure 1a, the largest increase in residual subsidence was $-148.1 \mathrm{~mm}$ over the entire observation period or an annual average of $-17.7 \mathrm{~mm} /$ year (coordinates of $11.872 \mathrm{~km}$ east-west and $11.119 \mathrm{~km}$ north-south).

\subsection{Uplift}

For the same sub-areas in Figure 3a, Figure 3b shows the average variation of the uplift for the satellite images from December 2003 through October 2010. Therefore, each curve began in December 2003, but the origin of the time is the same as it was for Figure 3a, i.e., when the last panel was mined within the extended sub-area, and the same size of the sub-area was considered. Hence, the number of reflectors on which the average is based is larger than in Figure 3a (see Table 1), i.e., 18 to 20 reflectors rather than the fixed number of 10 . 
Figure $3 \mathrm{~b}$ shows that the surface is still moving upwards about 20 years after the mine was closed and that the strata still are not stable even though the mining in the immediate vicinity was done 50 years ago, as is the case for the green sub-area. Table 1 indicates that the average annual rate of uplift for these four sub-areas varies between $6.2 \mathrm{~mm} /$ year (red sub-area) and $9.9 \mathrm{~mm} /$ year (blue sub-area). As mentioned earlier, the sub-areas were selected due to their relatively high uplift values. The maximum uplift is about $12 \mathrm{~mm} /$ year for the black and blue sub-areas. For the entire area presented in Figure 1b, the largest increase in uplift was $246.3 \mathrm{~mm}$ over the entire observation period or an average of $35.6 \mathrm{~mm} /$ year (coordinates of $11.210 \mathrm{~km}$ east-west and $6.757 \mathrm{~km}$ north-south).

Figure 5 a presents the minimum, average, and maximum uplift for the blue sub-area, which is characterized by the largest uplift of all of the sub-areas that were considered. Figure $5 \mathrm{~b}$ shows the curves for the brown sub-area, which corresponds to the lowest values of the uplift. Again, the variation over the entire observation period is presented without any extrapolation, and the origin of the time scale corresponds to the last panel mined in the vicinity. Figure $5 \mathrm{~b}$ shows that the change in the movement of the surface over the first 19 months was negligible, i.e., between the start of the observation in December 2003 through July 2005. It was only after July 2005 that the average curve started to increase significantly. This also is visible in Figure 5a to a lesser extent, but the period is limited to just the first 12 months. This is in accordance with earlier research [13]. As stated above, the limited surface movement was observed during the period of 2000-2004, but obvious uplift has been occurring since 2005 .

The variation between the minimum and maximum uplift as a function of time, or the so-called range, is relatively low, and it has been similar over the entire time period. For example, for the blue sub-area (Figure 5a), the range in uplift values has varied between $12.1 \mathrm{~mm}$ and $35.3 \mathrm{~mm}$ as a function of time, with an average range of $20.8 \mathrm{~mm}$. On average, the maximum uplift has been $9.1 \mathrm{~mm}$ larger than the average, and the minimum uplift has been $11.7 \mathrm{~mm}$ smaller than the average. Over the entire time of the observation, the average rate of uplift was $9.9 \mathrm{~mm} /$ year, with the extremes being 7.7 and $12.0 \mathrm{~mm} /$ year. As discussed for the residual subsidence, the differences between the minimum and maximum uplifts are the result of both the inaccuracy of the measurement method and the impact of the spatial variation.

\section{Discussion}

The examples presented earlier clearly show that the movement of the surface does not stop a few years after coal seams are mined at relatively large depths using the longwall method with goaf. Without a doubt, this occurrence is not limited to the Belgian Campine coal basin; rather, it very likely is valid for all coal basins with similar conditions. The most relevant characteristics are (1) depths of $-500 \mathrm{~m}$ and more, (2) the fact that several seams are mined above each other over depth intervals of several hundred meters, (3) that no chain pillars are used around the panels, and (4) that if a narrow zone of coal that is not mined between neighboring panels, it is crushed by the stress redistribution. So, for the case in which a single seam is mined at shallow depth with remaining chain pillars around the panels, it could be that the equilibrium already has been reached after a few years, but such conditions are not part of this research.

There probably are various reasons why it is almost always assumed that subsidence is limited in time. However, as explained above, this assumption is incorrect, at least for the conditions during the longwall mining in the Campine basin and in several other European coal basins with similar conditions. Probably, the most important reason is that, during the lifetime of a mine, it is very difficult, and may even be impossible, to distinguish the surface movements induced by the various longwall panels. At the end of mining a longwall panel, and sometimes even before the end, the mining of another panel in the vicinity is initiated, which also induces subsidence. This means that a point at the surface at a certain moment undergoes the impact of various longwall panels, i.e., those mined in the past (i.e., residual subsidence) and the one(s) currently being mined (initial and principal subsidence). Another reason is that, mainly in the past, people were less interested in the long-term impact of mining 
and gave little thought to the potential effects associated with the closure of a mine or the closure of a section of a mine. However, by introducing the concepts of sustainable mining, the long-term impact of mining on its surroundings has been receiving greater attention. This means that the period after the closure of a mine is a period that should not be neglected. It is obvious that during mining the amount of subsidence is largest. However, the impact of the smaller long-term surface movement rates on the already damaged or weakened buildings and infrastructure should not be neglected. In other words, a complete picture of the different phases is useful and necessary.

A reason which is more linked to practical considerations is that once the difference in surface movement between successive levelling campaigns becomes equal to the accuracy of the levelling method, or, in other words, the differences are very small (e.g., less than 10 or $20 \mathrm{~mm}$ ), one has the tendency to stop monitoring altogether. In one way, this is understandable since such levelling campaigns are costly and time-consuming. Nevertheless, a significant advantage of satellite images is that these data are collected, independent of the size of movement or a specific need for monitoring. Often, one also assumes that low subsidence rates have no impact on structures. However, the impact of a subsidence of $-0.5 \mathrm{~m}$ during a month, for example, probably is comparable to a subsidence rate of $-50 \mathrm{~mm} /$ year for 10 years or of $-5 \mathrm{~mm} /$ year for a century.

There also are some more general reasons why subsidence over very long periods has not been studied. Although research is being conducted on the time-dependent behavior of rock masses (e.g., Reference [18]), the time effect often is not included in an analysis, and hence, it is not well understood. For some types of rocks, e.g., for salt, clay, and shale, more research has been conducted on the time dependency because these rocks are sensitive to creep. However, the time intervals considered for these rocks are mostly in the range of days to months and are limited to the period immediately following the excavation. For example, Hawlader et al. [19] studied periods of up to 250 days for shaly rocks, and Bérest et al. [20] studied the impact of salt samples over nearly 700 days, but such studies are rather rare. Again, it is understandable that research projects that cover multiple years, or several decades, are not easy to organize, and the results only become available in the long-term. An interesting application where time periods of several centuries were studied was the failure of the historic masonry towers [21,22]. The collapse of these towers has been attributed to gradually increasing mechanical damage, such as creep cracking, which occurs under constant stress levels.

If masonry, with compressive strength of the same magnitude as weak-to-middle strong rocks and loaded by stress levels smaller than the strength, fails after several hundreds of years, one must assume that an assembly of broken and fractured weak rock blocks in the goaf zone will weaken further over a very long period. The flooding of the area also has an overall weakening effect on rock material, and two main mechanisms are involved. First, there is a direct weakening of various types of rock, e.g., shale, when they are submerged in water [23,24]. Wong et al. [23] concluded that, due to the considerable variations of texture and lithology, the extent of the water-weakening effect varies extensively among the different types of rocks, spanning from nearly negligible in quartzite to a $90 \%$ reduction of the uniaxial compressive strength in shale. They also specified for sedimentary rocks that, while sandstone mostly has losses in Young's modulus less than $20 \%$, other sedimentary rocks have much higher losses. These losses in shale exhibit a normal distribution with a mean of around $50 \%$. Some of the losses in the Young's modulus of mudstone can be $90 \%$ or more, while the losses of coal range between 30 and $40 \%$. Second, an increase in pore pressure brings the rock closer to the failure envelope through the concept of effective stresses. In other words, additional fractures can be induced by the decrease of the effective stresses. Due to all of these mechanisms, one should not be surprised that residual subsidence is more prevalent than generally assumed.

\section{Conclusions}

The remote sensing data show, without a doubt, that the strata above longwall coal mining for the conditions of the Belgian Campine basin are not stabilized after a few months or years. Surface movements of a magnitude of about $10 \mathrm{~mm} /$ year have been measured several decades after mining [25]. 
There is a clear difference between the movement of the surface above the undermined area and the zones around this area.

This study and others also have shown that a new phenomenon in surface movement occurs after the closure of the mines and the flooding of the underground infrastructure and surrounding rock mass. It is important to note that the uplift is not a simple rebound of the past subsidence. The spatial variation of the residual subsidence is different from that of the uplift values [17]. Other studies of European coal basins have shown clearly that uplift is linked directly to flooding of the underground [26,27]. Currently, we conduct further studies of the mechanisms of this uplift, but it is most likely a combination of the impact of the water pressure on the effective stresses, and hence, on the relaxation of the rock, and it possibly could be due to the impact of the swelling of clay minerals. A question which cannot be answered at this time is whether the uplift is limited in time. In the eastern part of the Belgian Campine basin, uplift already has been occurring for about 30 years, and there are no signs that it will stop soon. However, if the phenomenon is governed by re-establishing the original distribution of the pore pressure, it can be concluded that the uplift will stop once this is done.

Another unanswered question is whether the measured uplift is the result of downward and upward movement, i.e., whether the residual subsidence is still ongoing. In fact, it can be assumed that there is no reason or indication why the residual subsidence would have stopped. This would mean that the real upward component in the resulting movement is about twice as large as the uplift values presented above. Then, the difference in the spatial distributions of the residual subsidence and uplift also would be larger.

Therefore, if the uplift component were to stop at a certain time, there is, in fact, no reason why the resulting movement would not be downward again, since there are no signs that the residual subsidence will stop soon. When the blocks of rock are submerged in water, they are weakened, and hence, the compression of the goaf material even can increase. In a similar way, the increase of the pore pressure brings the rock closer to the failure envelopes, resulting in a larger probability of fracturing, and thus, weakening.

Since we are confronted with a relatively new phenomenon, i.e., the occurrence of uplift above closed coal mines, it is logical that there are no complete answers to all of the questions regarding these observations at this stage. Thus, it is obvious that additional research is needed. So, if one would ask the question of how long the impact of coal mining on surface movement will last, one cannot answer it at this moment, but perhaps it could last even centuries. However, it is reasonable to conclude that it will be a period of time much longer than those that normally are used in the planning and design of rock mechanical excavations.

Mining always has a certain impact on the land use. The use of a total extraction method without any backfill always leads to a significant amount of surface movement. For shallow mining, this can mean in certain cases that the surface area can never be used again for building purposes, even sometimes for agricultural use. For deep mining, the consequences are not always so stringent. In the case of the Campine coal basin, mining took place under villages and towns. This created damage to buildings and infrastructure during the mining phase. However, as the surface movement does not stop after a few years, buildings are further deformed and, hence, the risk of additional damage remains. The large values of initial subsidence also have resulted in whole surface areas that would have been flooded, if the surface water had not been pumped out. And these areas can only remain dry by pumping out the surface water for ever. If one would stop these pumps, these areas would fast submerge. Additional surface movement over long time periods, either residual subsidence or uplift, will not lead to new types of restrictions to the land use, but the surface areas under threat of being submerged can increase or can be shifted, and the natural flow in small waterways can be affected too. So, even small rates of surface movements can have after several decades a significant impact on the required water management. 
The main overall conclusion of the results presented in this paper is that both mining companies and legislators should be well aware of the long-term impact of mining and this should be taken into account when one defines the legal and the financial responsibilities of mining companies after closure.

Funding: This research received no external funding.

Conflicts of Interest: The author declares no conflict of interest.

\section{References}

1. Peng, S.S. Surface Subsidence Engineering; SME: New York, NY, USA, 1992.

2. Galvin, J.M. Ground Engineering - Principles and Practices for Underground Coal Mining; Springer International Publishing: Cham, Switzerland, 2016.

3. Huang, Y.; Zhang, J.; Yin, W.; Sun, Q. Analysis of overlying strata movement and behaviors in caving and solid backfilling mixed coal mining. Energies 2017, 10, 1057. [CrossRef]

4. Zhang, B.; Ye, J.; Zhang, Z.; Xu, L.; Xu, N. A comprehensive method for subsidence prediction on two-seam longwall mining. Energies 2019, 12, 3139. [CrossRef]

5. Vervoort, A. Various phases in surface movements linked to deep coal longwall mining: From start-up till the period after closure. Int. J. Coal Sci. Technol. 2020. [CrossRef]

6. Luo, Y.; Peng, S.S. Long-term subsidence associated with longwall mining-Its causes, development and magnitude. Min. Eng. 2000, 52, 49-54.

7. Al Heib, M.; Nicolas, M.; Noirel, J.F.; Wojtkowiak, F. Residual subsidence analysis after the end of coalmine work. Example from Lorraine colliery, France. In Proceedings of the Symposium Post Mining, Nancy, France, 16-17 November 2005; pp. 1-9.

8. Cui, X.; Zhao, Y.; Wang, G.; Zhang, B.; Li, C. Calculation of residual surface subsidence above abandoned longwall coal mining. Sustainability 2020, 12, 1528. [CrossRef]

9. Kajzar, V. Geodetic and seismological observations applied for investigation of subsidence formation in the CSM mine (Czech Republic). Min. Miner. Depos. 2018, 12, 34-46. [CrossRef]

10. Van Tongeren, P.; Dreesen, R. Residual space volumes in abandoned coal mines of the Belgian Campine basin and possibilities for use. Geol. Belg. 2004, 7, 157-164.

11. Vervoort, A. Surface movement above an underground coal longwall mine after closure. Nat. Hazards Earth Syst. Sci. 2016, 16, 2107-2121. [CrossRef]

12. Pöttgens, J.J. Uplift as a result of rising mine waters. In The Development Science and Art of Minerals Surveying, Proceedings of the 6th International Congress of the International Society for Mine Surveying, Harrogate, UK, 9-13 September 1985; August Aimé Balkema: Rotterdam, The Netherlands, 1985; Volume 2, pp. 928-938.

13. Vervoort, A.; Declercq, P.Y. Surface movement above old coal longwalls after mine closure. Int. J. Min. Sci. Technol. 2017, 27, 481-490. [CrossRef]

14. Devleeschouwer, X.; Declercq, P.Y.; Flamion, B.; Brixko, J.; Timmermans, A.; Vanneste, J. Uplift revealed by radar interferometry around Liège (Belgium): A relation with rising mining groundwater. In Proceedings of the Symposium Post Mining, Nancy, France, 6-8 February 2008; pp. 1-13.

15. Marinkovic, P.; Ketelaar, G.; van Leijen, F.; Hanssen, R.F. INSAR quality control: Analysis of five years of corner reflector time series. In Proceedings of the Fringe 2007 Workshop, Frascati, Italy, 26-30 November 2007; pp. 1-8.

16. Agioutantis, Z.; Robertson, J.; Gollaher, G.; Schaefer, N.; Silva, J.; Tripolitsiotis, A.; Partsinevelos, P. Permanent scatterer radar interferometry as an effective structure deformation monitoring tool over undermined areas. In Proceedings of the 7th International Conference on Remote Sensing and Geoinformation of the Environment, Paphos, Cyprus, 18-21 March 2019; pp. 1-16. [CrossRef]

17. Vervoort, A. Long-term impact of coal mining on surface movement: Residual subsidence versus uplift. Min. Rep. Glückauf 2020, 156, 136-141.

18. Malan, D.F. Simulating the time-dependent behaviour of excavations in hard rock. Rock Mech. Rock Eng. 2002, 35, 225-254. [CrossRef]

19. Hawlader, B.C.; Lee, Y.N.; Lo, K.Y. Three-dimensional stress effects on time-dependent swelling behaviour of shaly rocks. Can. Geotech. J. 2003, 40, 501-511. [CrossRef] 
20. Bérest, P.; Béraud, J.F.; Brouard, B.; Blum, P.A.; Charpentier, J.P.; de Greef, V.; Gharbi, H.; Valès, F. Very slow creep tests on salt samples. Epj Web Conf. 2010, 6, 22002. [CrossRef]

21. Verstrynge, E.; Schueremans, L.; Van Gemert, D.; Hendriks, M.A.N. Modelling and analysis of time-dependent behaviour of historical masonry under high stress levels. Eng. Struct. 2011, 33, 210-217. [CrossRef]

22. Verstrynge, E.; Van Gemert, D. Creep failure of two historical masonry towers: Analysis from material to structure. Int. J. Mason. Res. Innov. 2018, 3, 50-71. [CrossRef]

23. Wong, L.N.Y.; Maruvanchery, V.; Liu, G. Water effects on rock strength and stiffness degradation. Acta Geotech. 2016, 11, 713-737. [CrossRef]

24. Cai, X.; Zhou, Z.; Liu, K.; Du, X.; Zang, H. Water-weakening effects on the mechanical behavior of different rock types: Phenomena and mechanisms. Appl. Sci. 2019, 9, 4450. [CrossRef]

25. Vervoort, A.; Declercq, P.Y. Upward surface movement above deep coal mines after closure and flooding of underground workings. Int. J. Min. Sci. Technol. 2018, 28, 53-59. [CrossRef]

26. Caro Cuenca, M.; Hooper, A.J.; Hanssen, R.F. Surface deformation induced by water influx in the abandoned coal mines in Limburg, The Netherlands observed by satellite radar interferometry. J. Appl. Geophys. 2013, 88, 1-11. [CrossRef]

27. Samsonov, S.; d'Oreye, N.; Smets, B. Ground deformation associated with post-mining activity at the French-German border revealed by novel InSAR time series method. Int. J. Appl. Earth Obs. Geoinf. 2013, 23, 142-154. [CrossRef]

(C) 2020 by the author. Licensee MDPI, Basel, Switzerland. This article is an open access article distributed under the terms and conditions of the Creative Commons Attribution (CC BY) license (http://creativecommons.org/licenses/by/4.0/). 